Jurnal Keperawatan Silampari

Volume 5, Nomor 1, Desember 2021

e-ISSN: 2581-1975

p-ISSN: 2597-7482

DOI: https://doi.org/10.31539/jks.v5i1.2270

\title{
TEKNIK RELAKSASI PERNAPASAN TERHADAP FREKUENSI BERKEMIH PADA LANSIA
}

\author{
Andri Kusuma Wijaya ${ }^{1}$, Nurhayati ${ }^{2}$, Selvia Novitasari ${ }^{3}$ \\ Universitas Muhammadiyah Bengkulu ${ }^{1,2,3}$ \\ andrikwijaya@umb.ac.id ${ }^{1}$
}

\begin{abstract}
ABSTRAK
Penelitian ini bertujuan untuk mengetahui pengaruh teknik relaksasi pernapasan terhadap frekuensi berkemih atau inkotinensia urine terhadap lansia di Panti Sosial Tresna Werdha Pagar Dewa Bengkulu. Penelitian ini menggunakan desain penelitian pra eksperimental one- group pretest-posttest. Hasil penelitian ditemukan sebagian besar responden berjenis kelamin perempuan yaitu $9(60 \%)$ dan yang berjenis kelamin lakilaki $6(40 \%)$, sementara berdasarkan tingkat pendidikan sebagian besar responden memiliki tingkat pendidikan rendah yaitu $13(86,7 \%)$ untuk pendidikan tinggi terdapat 2 responden $(13,3 \%)$. Hasil analisis bivariat teknik relaksasi pernapasan terhadap frekuensi berkemih pada lansia dengan $(p$ value $=0$, 000). Simpulan, ada pengaruh Teknik Relaksasi Pernapasan terhadap Frekuensi Berkemih Pada Lansia di Panti Sosial Tresna Werdha Pagar Dewa Bengkulu.
\end{abstract}

Kata Kunci: BAK, Relaksasi

\section{ABSTRACT}

This study aims to determine the effect of breathing relaxation techniques on the frequency of urination or urinary incontinence for the elderly at the Tresna Werdha Pagar Dewa Social Home Bengkulu. This study used a one-group pretest-posttest preexperimental research design. The results of the study found that most of the respondents were female, namely $9(60 \%)$ and male, $6(40 \%)$, while based on education level, most of the respondents had a low level of education, namely 13 (86.7\%) for higher education. there are 2 respondents (13,3\%). The results of the bivariate analysis of breathing relaxation techniques on the frequency of urination in the elderly ( $p$-value $=0.000$ ). In conclusion, there is an effect of the Breathing Relaxation Technique on the Frequency of Urination in the Elderly at the Tresna Werdha Pagar Dewa Social Institution, Bengkulu.

Keywords: BAK, Relaxation

\section{PENDAHULUAN}

Lanjut usia adalah seseorang yang telah mencapai atau memasuki usia 60 (enam puluh) tahun keatas. Proses menua (aging proces) biasanya akan ditandai dengan adanya perubahan fisik-biologis, mental ataupun psikososial. Menua adalah proses terjadinya perubahan pada semua sistem tubuh salah satunya adalah sistem syaraf. Perubahan pada sistem syaraf mempengaruhi kerja fungsi otak yang menyebabkan penurunan pada memori jangka pendek dan panjang pada lansia sehingga diperlukan 
upaya - upaya yang mempunyai prinsip penyandian memori jangka pendek dan panjang sehingga dapat mempermudah penyimpanan informasi pada lansia (Andri et al., 2019; Ani et al., 2020; Fazriana, 2020).

Penurunan fungsi pada sistem perkemihan pada lansia salah satunya terjadinya penurunan fungsi kandung kemih dimana ini merupakan proses fisiologis pada seorang lansia yang disebabkan oleh tidak terarutnya otot sfingter dalam melakukan proses kontraksi sehingga kandung kemih menjadi lemah dan menyebabkan peningkatan frekuensi berkemih atau terjadi perubahan frekuensi miksi (Lestari et al., 2021).

Perubahan frekuensi miksi yang dimaksudkan ialah inkontinensia urine sebuah kondisi dimana urine keluar secara tidak terkendali dalam rentan waktu yang tidak diharapkan serta inkotinensia urine merupakan keluhan utama yang terjadi pada sebagian lansia dan bukan merupakan konsekuensi normal yang terjadi sehingga hal ini perlu mendapatkan penanganan secara berlanjut (Kamariyah \& Oktarina, 2020).

Berdasarkan hasil data dari WHO ditemukan ada 200 juta jumlah penduduk di dunia ini yang sedang mengalami gangguan terkait inkotinensia urine. Sementara data menurut national kidney and urologyc diseasead visory board di Amerika Serikat, ada penderita inkotinensia urine dengan jumlah penderita mencapai 13 juta dengan persentase hampir $85 \%$ terjadi pada penderita dengan jenis kelamin perempuan. Kondisi ini pada dasarnya masih sedikit dari keadaan sebenarnya karena masih banyak sekali kasus yang tidak dilaporkan secara langsung (Harahap et al., 2020).

Meningkatnya angka kejadian gangguan pemenuhan kebutuhan eliminasi urin pada lansia, maka dibutuhkan penatalaksanaan yang efektif agar masalah ini dapat dicegah atau minimalisir dampaknya, atau paling tidak tingkat keparahannya dapat dikurangi karena pada dasarnya gangguan frekuensi berkemih mempunyai kemungkinan yang besar untuk dihambat. Salah satu terapi untuk menurunkan masalah frekuensi berkemih ialah dengan melakukan relaksasi pernafasan. Teknik relaksasi pernapasan merupakan upaya yang sangat penting dalam perawatan pasien dengan bermacam gangguan (Padila et al., 2019). Manfaat terapi ini salah satunya meringankan inkontinensia urine pada lansia dan untuk memodifikasi perilaku kesehariannya terhadap kontrol kandung kemih. Dengan melakukan terapi tersebut bertujuan memperpanjang interval saat berkemih dan volume miksi yang lebih banyak sehingga gangguan Frekuensi berkemih yang dialami lansia dapat berkurang.

Berdasarkan survey pendahuluan yang telah dilakukan di Panti Sosial Tresna Werdha Pagar Dewa Bengkulu pada tanggal 13 sd 17 Juli 2020 jumlah dari 85 orang lansia yang menghuni Panti yang sering dikenal dengan nama Panti Sosial Tresna Werdha Pagar Dewa Bengkulu setelah diwawancarai didapatkan ada 18 lansia yang mengalami gejala inkotinensia urin atau frekuensi buang air kecil melebihi ambang normal > 8 kali sehari serta lansia juga mengungkapkan bahwa belum pernah mendapatkan intervensi non farmakologi untuk mengatasi masalah tersebut seperti teknik pernapasan untuk mengurangi kebiasaan berkemih yang lebih dari normal.

\section{METODE PENELITIAN}

Desain Penelitian yang diaplikasikan dalam kegiatan penelitian ini ialah dengan menggunakan desain pra exsperimental one group pretest-posttest yang digunakan untuk melihat pengaruh teknik relaksasi pernapasan terhadap frekuensi berkemih lansia yang menjadi penghuni di Panti Sosial Tresna Werdha (PSTW) Pagar Dewa Bengkulu. Penelitian ini dilaksanakan bulan Februari sampai dengan Maret 2021 yang dilakukan di Panti Sosial Tresna Werdha Pagar Dewa Bengkulu. 
Populasi adalah keseluruhan objek penelitian yang diteliti. Populasi yang terlibat dalam kegiatan penelitian ini adalah seluruh lansia yang mengalami kondisi frekuensi berkemih lebih dari normal di Panti Sosial Tresna Werdha (PSTW) Pagar Dewa Bengkulu

Sampel penelitian merupakan sekelompok individu yang menjadi bagian dari populasi terjangkau dimana langsung mengumpulkan data atau melakukan pengamatan atau pengukuran pada unit ini. Besar sampel dalam kegiatan penelitian ini ialah sebanyak 15 orang yang diberikan terapi teknik pernapasan.

Teknik pengambilan sampel pada penelitian ini adalah simple random sampling yaitu metode dengan melakukan pengambilan dari sampel dengan teknik secara acak sederhana dengan asumsi kriterian tertentu yang memenuhi kriteria inklusi. Dimana kriteria inklusi dan eksklusi tersebut adalah sebagai berikut.

Kriteria inklusi: Lansia yang Mengalami frekuensi berkemih lebih dari normal. Lansia yang dapat berkomunikasi verbal. Lansia yang tidak mengalami tuna rungu. Lansia yang dapat mengikuti proses penelitian sampai selesai.

Kriteria Eksklusi; Lansia dengan gangguan mental. Lansia post oprasi. Mempunyai penyakit penyerta seperti diabetes mellitus yang dimungkinkan mengalami kesulitan dalam menahan berkemih. Lansia tidak dapat menyelesaikan jalannya penelitian sampai selesai

Prosedur pengumpulan data hasil dari kegiatan penelitian ini dilakukan mulai dari tahapan mengurus perijinan untuk melakukan penelitian. Setelah izin dikeluarkan oleh pihak DPMTSP dan pihak panti, peneliti melakukan kegiatan penelitian dimulai dari seleksi terhadap calon responden yang didasarkan pada kriteria inklusi. Bukti sahih responden bersedia menjadi responden adalah dengan kesediaan berupa penandatanganan lembar informed concent. setelah responden bersedia mengikuti penelitian ini peneliti melakukan kegiatan dengan menanyakan terkait identitas responden kemudian dilanjutkan dengan menanyakan frekuensi berkemih pre intervensi yang merupakan akibat yang di tuliskan instrumen yang telah disusun oleh peneliti. Setelah frekuensi berkemih didapatkan peneliti menjelaskan teknik yang dapat dilakukan berupa latihan relaksasi pernapasan kepada responden.

Selanjutnya responden diposisikan ke posisi senyaman mungkin meminta klien untuk memulai teknik relaksasi pernapasan. Peneliti menganjurkan klien untuk menggunakan latihan ini dan meningkatkannya secara bertahap 5-10 menit. Setelah dilakukan tindakan relaksasi pernapasan selama 12 hari berturut-turut tindakan selanjutnya berupa mengukur kembali frekuensi berkemih lansia dan dituliskan kedalam lembar observasi responden. Hasil penelitian ini diuraikan melalui dua tahapan yang meliputi analisis univariat dan analisis bivariat dimana menggunakan uji dependen t-test atau paired t-test

\section{HASIL PENELITIAN}

Analisi Univariat

Tabel. 1

Distribusi Responden Berdasarkan Jenis Kelamin Lansia dengan

\begin{tabular}{|c|c|c|}
\hline Jenis Kelamin & $N$ & Persentase (\%) \\
\hline Laki-Laki & 6 & 40 \\
\hline Perempuan & 9 & 60 \\
\hline Total & 15 & 100 \\
\hline
\end{tabular}


Berdasarkan tabel 1 menunjukan bahwa jenis kelamin responden dengan frekuensi berkemih tidak normal di Panti Sosial Tresna Werdha (PSTW) Pagar Dewa Bengkulu sebagian besar jenis kelamin perempuan yaitu $9(60 \%)$ yang berjenis kelamin laki-laki $6(40 \%)$

Tabel. 2

Distribusi Responden Berdasarkan Tingkat Pendidikan Lansia

\begin{tabular}{ccc}
\hline Tingkat Pendidikan & $N$ & Persentase (\%) \\
\hline Pendidikan Rendah (SD-SMP) & 13 & 86,7 \\
Pendidikan Tinggi (SMA -PT) & 2 & 13,3 \\
\hline Total & 15 & 100
\end{tabular}

Berdasarkan tabel 2 distribusi responden berdasarkan tingkat pendidikan lansia dengan gangguan berkemih di Panti Sosial Tresna Werdha (PSTW) Pagar Dewa Bengkulu sebagian besar masuk ke kategori pendidikan rendah yaitu 13 (86,7 \%). Sementara sebagian lagi masuk kekategori pendidikan tinggi yang berjumlah 2 orang $(13,3 \%)$.

\section{Analisis Bivariat}

Tabel. 3

Distribusi Rata-Rata Frekuensi Berkemih Responden Sebelum dan Setelah Intervensi Berupa Teknik Relaksasi Pernapasan pada Lansia

\begin{tabular}{lcccc}
\hline Variabel & Mean & $S D$ & P Value & $N$ \\
\hline Frekuensi Berkemih & & & & \\
Sebelum Intervensi & 9,86 & 1,80 & 0,000 & 15 \\
Setelah Intervensi & 7,66 & 1,83 & & \\
\hline
\end{tabular}

Berdasarkan tabel 3 didapatkan hasil analisis berupa rata-rata frekuensi berkemih sebelum pemberian intervensi berupa teknik relaksasi pernapasan adalah 9,86 dengan standar deviasi 1,80 . Setelah pemberian intervensi berupa teknik relaksasi pernapasan didapatkan rata-rata frekuensi berkemih adalah 7,66 dengan standar deviasi 1,83. Hasil uji dengan analisis statistik didapatkan nilai $\mathrm{P}$ Value 0,000 maka dapat disimpulkan bahwa ada pengaruh yang signifikan antara frekuensi berkemih sebelum dan setelah pemberian intervensi berupa teknik relaksasi pernapasan pada lansia dengan di Panti Sosial Tresna Werdha (PSTW) Pagar Dewa Bengkulu.

\section{PEMBAHASAN}

\section{Analisis Univariat}

Berdasarkan tabel 1 menunjukan bahwa jenis kelamin responden dengan gangguan frekuensi berkemih sebagian besar dialami oleh perempuan dimana dari 15 lansia yang mengalami gangguan frekuensi berkemih sebagian besar terjadi pada perempuan $9(60 \%)$ sementara yang terjadi pada laki-laki berjumlah 6 (40\%). Hasil penelitian ini sejalan dengan penelitian yang dilakukan oleh Haris \& Emilyani (2019) dimana hasil penelitian tersebut untuk jenis kelamin lanjut usia yang mengalami gangguan frekuensi berkemih dari 10 responden didapatkan data jenis kelamin perempuan ternyata lebih banyak, dimana responden perempuan berjumlah 6 orang $(60 \%)$, sedangkan responden berjenis kelamin laki-laki 4 orang $(40 \%)$. 
Hasil penelitian ini diperkuat juga oleh penelitian yang dilakukan oleh Suhartiningsih et al., (2021) dimana hasil penelitian terkait pengaruh senam kegel latihan kegel terhadap inkotinensia urine atau gangguan frekuensi berkemih pada lansia di Balai Sosial Lanjut Usia Mandalika Mataram dengan hasil berupa sebagian besar inkotinensia urine terjadi pada perempuan yaitu 21 lansia perempuan $(81 \%)$ sementara laki-laki berjumlah 5 Lansia (19\%). Hasil dari pada penelitian ini juga mendukung penjelasan teori yang mengungkapkan dimana jenis kelamin perempuan lebih beresiko mengalami inkontinensia urine atau gangguan frekuensi berkemih dibandingkan dengan laki-laki. Perempuan yang beresiko mengalami gangguan frekuensi berkemih juga berpeluang mengalami masalah kesehatan lainnya. Perempuan juga memiliki resiko mengalami gangguan frekuensi berkemih 4 kali lebih banyak dibandingkan dengan jenis kelamin laki laki dimana hal ini disebabkan oleh faktor resiko karena adanya riwayat melahirkan, tindakan operasi. Selanjutnya riwayat proses persalinan merupakan faktor resiko terjadinya ikotinensia urine. Kondisi persalinan yang lama mampu menyebabkan penurunan otot pada kandung kemih yang berdampak terhadap perempuan lebih berisiko mengalami gangguan frekuensi berkemih (Suyanto, 2019).

Menurut peneliti keadaan dimana menyebabkan lansia dengan jenis kelamin perempuan memiliki resiko yang lebih tinggi untuk mengalami frekuensi berkemih dengan kategori tidak normal atau $\geq 8 \mathrm{kali} /$ hari hal ini dikarenakan terjadinya penurunan otot pada vesika urinaria yang disebabkan oleh faktor seperti proses melahirkan dengan waktu yang lama sehingga berakibat pada peningkatan frekuensi berkemih pada lansia.

Berdasarkan tabel 2 dapat diperoleh hasil bahwa sebagian besar masuk ke kategori pendidikan rendah. Hasil penelitian sejalan dengan penelitian yang dilakukan oleh Wilis (2018) didapatkan hasil berupa dari 33 responden yang ikut serta diketahui dimana hampir sebagian besar responden dengan akumulasi sebanyak 21 responden $(63,6 \%)$ berpendidikan kategori terakhir SMP atau berpendidikan rendah.

Penelitian lain mengungkapkan hal yang sama dimana didapatkan hasil distribusi lansia yang mengalami inkotinensia urine dilihat dari dasar tingkat pendidikan diperoleh hasil berupa lansia dengan latar belakang pendidikan rendah berjumlah 9 lansia $(64,28$ $\%)$, lansia dengan latar belakang pendidikan sedang berjumlah 4 lansia $(28,57 \%)$ dan lansia dengan latar belakang pendidikan tinggi berjumlah 1 lansia $(7,15 \%)$ (Amelia, 2020).

Hal ini diperkuat oleh ungkapan Wijaya et al., (2018) dimana seorang klien atau pasien dengan tingkat pendidikan yang rendah akan lebih sulit dalam mengambil sebuah keputusan terutama dalam hal pencegahan dan sedikitnya kesadaran terhadap faktorfaktor yang mampu menyebabkan kekambuhan suatu masalah kesehatan yang sedang dialaminya. Sehingga menurut peneliti lansia yang mengalami gangguan frekuensi berkemih sebagian besar berada pada tingkat pendidikan yang rendah hal ini tentunya berdampak pada munculnya kebimbangan untuk mengambil keputusan yang tepat terkait tindakan pencegahan gangguan berkemih pada lansia misalnya pola makan, minum, psikososial, aktivitas seperti berolah raga.

\section{Analisis Bivariat}

Berdasarkan tabel 3 didapatkan hasil analisis berupa rata-rata frekuensi berkemih sebelum pemberian intervensi berupa teknik relaksasi pernapasan adalah 9,86 dengan standar deviasi 1,80. Setelah pemberian intervensi berupa teknik relaksasi pernapasan didapatkan rata-rata frekuensi berkemih adalah 7,66 dengan standar deviasi 1,83. Hasil uji statistik menunjukkan bahwa ada pengaruh yang signifikan antara frekuensi 
berkemih sebelum dan setelah pemberian intervensi berupa teknik relaksasi pernapasan pada lansia di Panti Sosial Tresna Werdha (PSTW) Pagar Dewa Bengkulu.

Hasil penelitian ini sejalan dengan penelitian Haris \& Emilyani (2019) dimana hasil penelitian dengan responden yang mengalami inkontinensia urine (gangguan frekuensi berkemih) berat sebanyak 2 orang dan responden yang mengalami inkontinensia (gangguan frekuensi berkemih) sedang sebanyak 8 orang, setelah diberikan teknik relaksasi responden yang mengalami inkontinensia urine (gangguan frekuensi berkemih) ringan sebanyak 6 orang dan responden yang mengalami inkontintinensia urine (gangguan frekuensi berkemih) sedang sebanyak 4 orang dalam hal ini dapat dilihat bahwa ada pengaruh teknik relaksasi terhadap inkontinensia urine (gangguan frekuensi berkemih) pada lansia di Panti Sosial Tresna Werdha "Meci Angi “ Bima. Sementara hasil perhitungan statistiknya menyatakan bahwa ada pengaruh gangguan frekuensi berkemih sebelum diberikan teknik relaksasi dan sesudah diberikan teknik relaksasi. Seorang lansia akan mengalami peningkatan frekuensi berkemih terutama pada malam hari yang disebabkan oleh kontrakbilitas dan kelemahan dari tonus otot kandung kemih dimana tonus otot yang tidak baik dapat berakibat pada kontraksi otot kandung kemih melemah serta kontrol sfingter uretra eksternal tidak baik sehingga tidak mampu untuk mengontrol miksi.

Ada beberapa pentalaksanaan nonfarmakologis dari masalah inkotinensia urine yaitu berupa teknik relaksasi yang mampu membuat frekuensi berkemih hanya 6-7 kali perhari atau kalau disederjanakan 3-4 jam sekali (Suminar \& Islamiyah, 2020). Maka dari pada itu tindakan relaksasi pernapasan merupakan salah satu tindakan yang tepat untuk meningkatkan aktivitas tonus otot dan kontraksi kandung kemih. Dalam hal ini oksigenisasi darah yang adekuat terutama pada daerah otak akan mengurangi resiko terjadinya gangguan frekuensi berkemih.

Hal ini diperkuat dimana gangguan frekuensi berkemih dapat terjadi karena ketidakmampuan untuk menunda berkemih ketika sensasi untuk berkemih itu muncul, jumlah urine yang dikeluarkan sedikit serta frekuensi yang terlalu sering. Masalah neurologik sering kali berhubungan dengan gangguan frekuensi berkemih ini yang disebabkan oleh seperti halnya stroke yang dapat dipicu juga oleh ketidakadekutan suplai oksigenisasi darah kebagian otak. Teori lain juga mengatakan dimana menurut Haris \& Emilyani, menerangkan bahwa teknik relaksasi bertujuan untuk melatih pasien sehingga mampu mengenal timbulnya sensasi urgensi, dengan harapan akan mencoba menghambat dan selanjutnya terjadi penundaan saat miksi atau buang air kecil. Latihan ini pada dasarnya dapat dilakukan dengan teknik relaksasi. Dalam kondisi ini lansia dianjurkan untuk miksi atau buang air kecil pada interval waktu tertentu seperti setiap 23 jam serta diharapkan dapat menahan keinginan untuk berkemih sehingga nantinya frekwensi berkemih lansia dapat mecapai jumlah $6-7$ kali perhari (Haris \& Emilyani, 2019).

Menurut peneliti pengalihan dengan melatih teknik relaksasi pernapasan diharapkan mampu membiasakan lansia untuk memperpanjang durasi berkemih sehingga frekuensi berkemih lansia tidak berlebihan. Selain itu teknik relaksasi pernapasan mampu meningkatkan kebutuhan oksigenisasi dari seorang lansia yang juga dibutuhkan untuk meningkatkan kinerja neurologi sehingga memicu terjadinya sensasi urgensi yang dengan manfaat lansia akan lebih mampu mengontrol miksi yang dilakukan sehari-hari. 


\section{SIMPULAN}

Ada pengaruh teknik relaksasi pernapasan terhadap frekuensi berkemih pada lansia di Panti Sosial Tresna Werdha Pagar Dewa Bengkulu.

\section{SARAN}

Diharapkan penentu kebijakan di Panti Sosial Tresna Werdha Pagar Dewa Bengkulu agar dapat memberikan informasi tentang pentingnya pentalaksanaan nonfarmakologi untuk meminimalisir gangguan frekuensi berkemih seperti melakukan intervensi teknik relaksasi pernapasan dalam rangka meningkatkan derajat kesehatan lansia.

Untuk pengembang ilmu keperawatan diharapkan dapat menjadi sebuah pengetahuan khususnya untuk mahasiswa keperawatan dalam memberikan pelayanan ketika melakukan praktik untuk membantu mengatasi permasalahan yang sering dihadapi oleh lansia seperti permasalahan gangguan frekuensi berkemih.

Sementara untuk pengembangan penelitian diharapkan dilakukan penelitian lebih lanjut dengan menambah variabel-variabel penelitian yang lain seperti misalnya mengkombinasi intervensi teknik relaksasi dengan intervensi lainya serta melakukan penelitian terkait faktor-faktor yang mempengaruhi terjadinya resiko gangguan frekuensi berkemih pada lansia.

\section{DAFTAR PUSTAKA}

Amelia, R. (2020). Prevalensi dan Faktor Risiko Inkontinensia Urin pada Lansia di Panti Sosial Tuna Werdha (PSTW) Sabai Nan Aluih Sicincin Pariaman. Health \& Medical Journal, 2(1), 39-44. https://doi.org/10.33854/heme.v2i1.264

Andri, J., Karmila, R., Padila, P., Harsismanto, J., \& Sartika, A. (2019). Pengaruh Terapi Aktivitas Senam Ergonomis terhadap Peningkatan Kemampuan Fungsional Lansia. Journal of Telenursing, 1(2), 304-313. https://doi.org/https://doi.org/10.31539/joting.v1i2.933

Ani, T., Faridah, A., \& Puji, P. (2020). Pengaruh Memory Training terhadap Fungsi Kognitif Lansia.Universitas Ngudi Waluyo. http://repository2.unw.ac.id/613/

Fazriana, E. (2020). Profil Fungsi Kognitif Berdasarkan Karakteristik Lansia Binaan Sahabat Lansia. Jurnal Keperawatan Silampari, 4(1), 314-321. https://doi.org/https://doi.org/10.31539/jks.v4i1.1457

Harahap, M. A., Rangkuti, N. A., \& Royhan, A. (2020). Inkontinensia Urine pada Lansia di Wilayah Kerja Puskesmas Pijorkoling Kota Padangsidimpuan. Jurnal $\begin{array}{llll}\text { Education } \quad \text { Development, } & \text { 8(4), 523-526. }\end{array}$ http://journal.ipts.ac.id/index.php/ED/article/view/2214

Haris, A. B., \& Emilyani, D. (2019). Pengaruh Teknik Relaksasi Pernapasan terhadap Inkontinensia Urine pada Usia Lanjut di PSTW "Meci Angi"Bima. Jurnal Analis Medika Biosains, 2(2), 302-311. https://scholar.google.com/scholar?hl=id\&as_sdt=0\%2C5\&q=inkotinesia+urine\% $2 \mathrm{C}+$ relaksasi+pernapasan $\&$ btnG $=$

Suhartiningsih, S., Cahyono, W., \& Egho, M. (2021). Pengaruh Senam Kegel terhadap Inkontinensia Urin pada Lansia di Balai Sosial Lanjut Usia Mandalika Mataram. Jurnal Ilmu Sosial dan Pendidikan, 5(3), 268-273. https://doi.org/10.36312/jisip.v5i3.2170 
Kamariyah, L. M., \& Oktarina, Y. (2020). Pengaruh Latihan Kegel terhadap Inkontinensia Urine pada Lansia di PSWT Budi Luhur Kota Jambi. Medic, 3(1), 48-53. https://online-journal.unja.ac.id/medic/article/view/8594

Lestari, R. P., Jauhar, M., \& Surachmi, F. (2021). Literature Review Studi Literatur: Senam Kegel Efektif Menurunkan Frekuensi Berkemih pada Lansia. Berkala Ilmiah Mahasiswa Ilmu Keperawatan Indonesia, 9(1), 29-38. https://doi.org/10.53345/bimiki.v9i1.175

Padila, P., Febriawati, H., Andri, J., \& Dori, R. A. (2019). Perawatan Infeksi Saluran Pernafasan Akut (ISPA) pada Balita. Jurnal Kesmas Asclepius, 1(1), 25-34. https://doi.org/https://doi.org/10.31539/jka.v1i1.526

Suminar, E., \& Islamiyah, L. (2020). Hubungan Paritas dengan Kejadian Inkontinensia Urin-Stres pada Wanita Usia 40-45 Tahun. Indonesian Journal of Professional Nursing, 1(1), 25. https://doi.org/10.30587/ijpn.v1i1.2017

Suyanto, A. (2019). Inkontinensia Urin pada Lansia Perempuan. Jurnal Keperawatan dan Kesehatan Masyarakat STIKES Cendekia Utama Kudus, 8(2), 127-198. https://jurnal.stikescendekiautamakudus.ac.id/index.php/stikes/article/view/411

Wijaya, A. K., Busjra, B., \& Azzam, R. (2018). Pengaruh Edukasi Pendekatan Spiritual Berbasis Video terhadap Kepatuhan Pembatasan Cairan Klien ESRD yang Menjalani Hemodialisa. Jurnal Keperawatan Silampari, 1(2), 17-31. DOI: $10.31539 /$ jks.v1i2.97

Wilis, N. (2018). Inkontinensia, Tugas Keluarga, Tugas Keluarga dalam Menghadapi Inkontinensia Urine pada Lansia. Jurnal Keperawatan Malang, 3(1), 7-15. https://doi.org/10.36916/jkm.v3i1.53 